SÖYLEM, İDEOLOJI, SÖYLEM, İDEOLOJi, SÖYLEM, İDEOLOJİ. . . ***

\author{
Makaleler (Tema)
}

Trevor Purvis ve Alan Hunt ${ }^{* * *}$

Çeviren: Simten Coşar ${ }^{* * * *}$

ISSN: 2148-970X DOI: https://doi.org/10.17572/mj2014.1.936

\title{
Özet
}

Modern sosyal teori 'söylem' ve 'ideoloji'yle dolup taşıor. İki kavram, bazen birbirinin yerine kullanılıyor, bazen karşı karşıya getiriliyor. Bu yazıda, bu iki kavramın günümüzde yürütülen tartışmalardaki rolünü anlamaya çalışıyoruz. Bunu yaparken, farklı teorik geleneklerden çıkan iki anahtar terimimizin birbirinden ayrı tutulabileceği gibi birlikte de çok işe yarayabileceğini ileri sürerek söylem ve ideoloji ilişkisini geri kazanmayı deniyoruz. İlk olarak, modern Batı Marksizmi'nde ideoloji üzerine yürütülen tartışmayı ele alıyoruz ve Larrain'in ideolojinin pozitif ve negatif kavramsallaştırması arasındaki farkı göz önüne almak gerektiği yönündeki cazip önerisini inceliyoruz. Ardından, söylem teorisinin Foucault tarafindan geliştirilen versiyonuna bakıyoruz. Üçüncü olarak, söylem ve ideoloji arasında bir kopuşu yeğleyen Ernesto Laclau ve Chantal Mouffe'un çalışmalarına odaklanıyoruz. Laclau ve Mouffe'un sundukları, izledikleri yolu — bizim önerdiğimiz yaklaşıma en yakın duran —ve söylem teorisinin sunduğu açllımlardan yararlanırken ideoloji kavramından vazgeçmeyen Stuart Hall'un savunduğu Gramscici konumla karşı karşıya getireceğiz.

Önerdiğimiz ideoloji teorisi, söylem teorisine karşı durmuyor; daha ziyade söylem teorisini tamamlıyor. Bu, Marx'ın miras bıraktığı ideoloji teorisinden farklıdır. Marx'ın bu konudaki açıklamalarına özgü eleştirelliği, diğer bir ifadeyle, özne konumlarına çağırılmanın, egemen toplumsal ilişkileri tahkim etmek ve yeniden üretmek üzere sistematik olarak işleyişini-ideoloji teorisinin "yön belirleme kapasitesi" denen tam da budur-odağa almasını devam ettiriyoruz ve buna merkezî önem atfediyoruz. $\mathrm{Bu}$ "yön belirleme kapasitesi" söylemsel pratiklerin etkilerine-_ideolojinin etkileri”" olarak adlandırıyoruz-odaklanmak için ideoloji analizini devreye soktuğumuzda açığa çıkıyor.

Anahtar terimler: İdeoloji, söylem, ideoloji etkileri, post-Marksizm, ortak kanı

\section{DISCOURSE, IDEOLOGY, DISCOURSE, IDEOLOGY, DISCOURSE, IDEOLOGY...}

\author{
Abstract \\ Modern social theory is awash with talk of "discourse" and "ideology". Sometimes the two \\ concepts are used interchangeably and at other times they are counterposed. The paper

\footnotetext{
* Purvis, T. ve Hunt, A. (1993). Discourse, ideology, discourse, ideology, discourse, ideology... The British Journal of Sociology, 44(3): 473-499. Yazarlardan ve dergiden izin alınarak Türkçe'de basılmıştır. (e.n.)

** Makalenin Geliş Tarihi: 17/03/2014. Kabul Ediliş Tarihi: 20/05/2014.

${ }^{* * *}$ Trevor Purvis, Prof., Carleton University, Department of Law and Legal Studies ve Alan Hunt, Prof., Carleton University, Department of Sociology/Anthropology. trevor.purvis@ carleton.ca

${ }^{* * * *}$ Prof. Dr., Hacettepe Üniversitesi, İletişim Fakültesi, Radyo Televizyon Sinema Bölümü. simcosar@gmail.com
} 
seeks to make sense of the part played by these concepts in contemporary debates. It proposes an exercise in retrieval which suggests that our two key terms form distinct theoretical traditions which, while they can be distinguished, can both be made good use of. We first engage with the debate over ideology within modern western Marxism and explore the suggestive distinction proposed by Larrain between a negative and a positive conception of ideology. Next we explore Foucault's version of discourse theory. Our third investigation focuses on the work of Ernesto Laclau and Chantal Mouffe who opt for a rupture between discourse and ideology; their solution will be contrasted with the Gramscian position espoused by Stuart Hall- the approach closest to the solution we will propose-that retains the concept ideology whilst benefiting from the advances secured by discourse theory.

The theory of ideology we propose supplements discourse theory rather than opposing it. It is a version of ideology theory that is different from that bequeathed by Marx. Retained and moved into central prominence is a key feature of the critical thrust of Marx's account, namely, its focus on the way in which the interpellation of subject positions operates systematically to reinforce and reproduce dominant social relations-it is this that is described as the "directionality" of ideology theory. This directionality is captured by employing ideological analysis to focus upon the effects of discur- sive practices, which we term "ideology effects".

Key terms: Ideology, discourse, ideology effects, post-Marxism, common sense

\section{Söylem: İdeolojinin Yanında mı; İdeolojiye Karşı mı?}

Modern sosyal teori "söylem" ve "ideoloji”yle dolup taşıyor. İki kavram, bazen birbirinin yerine kullanılıyor, bazen karşı karşıya getiriliyor. $\mathrm{Bu}$ kavramların bugünkü kullanımları sadece biçemsel bir tercih mi; ya da hattâ entelektüel bir heves oldukları söylenebilir mi? Althusser'in “ideoloji” kullandığı her örnekte, “ideoloji”nin yerine "söylem”i koysaydık, aynı anlama gelir miydi? Foucault'nun yazdığı metinler, "söylem" yerine “ideoloji” konularak yeniden basılsaydı, farklı bir Foucault'yla karşılaşır mıydık? Bu yazıda, bu kavramların günümüzde yürütülen tartışmalardaki rollerini anlamaya çalışıyoruz. Bunu yaparken, farklı teorik geleneklerden çıkan iki anahtar terimimizin birbirinden ayrı tutulabileceği gibi birlikte de çok işe yarayabileceğini ileri sürerek söylem ve ideoloji ilişkisini geri kazanmayı deniyoruz. Aralarında keskin bir ayrıştırmaya gitmeyi vaat etmiyoruz; daha ziyade toplumsal ilişkilerin analizinde her iki kavramın da birbirinden ayrıştırılabilir teorik rollere sahip olduklarını ileri süreceğiz.

Toplumsal olanla ilgili kavramlar, hiçbir zaman tam anlamıyla göndergesel değillerdir; diğer bir ifadeyle, muğlâk olmayan belirli bir dişsal gerçekliğe tekabül eden ya da işaret eden (ve dolayısıyla söz konusu gerçekliği temsil eden) sözel bir işareti tanımlamazlar. Daha ziyade, kavramlar, toplumsal olanı oluşturan bağlantılar ve ilişkiler bütününün belirli kesit[ler]ini anlaşılır kılarlar ya da ön plâna çıkarırlar. Bu anlamda, ideoloji ve söylem 
toplumsal hayatın hemen hemen aynı kesitine-insan bireylerin, dâhil oldukları ilişkiler ve faaliyetlerle ilgili anlaşılmasına, kavranmasına ya da bilinç oluşumuna katıldıkları fikrineişaret ederler. Bu toplumsal olanın hermenötik bir boyuta da sahip olacak, ancak hermenötiğe indirgenemeyecek şekilde kavramsallaştırılmasıdır. Bu bilinç, dil ve diğer işaret sistemleri vasıtasıyla ortaya çıkar, insanlar ve kurumlar arasında iletilir ve belki de en önemlisi, fark yaratır. Diğer bir ifadeyle, insanların toplumsal dünyayı kavrama ve anlamlandırma biçimleri eylemlerinin ve eylemsizliklerinin yönü ve niteliğini etkiler. Hem 'ideoloji' hem de 'söylem' toplumsal hayatın bu kesitlerine işaret ederler.

“Söylem” ve "ideoloji” kavramları arasında önemli farklar da vardır. Örneğin, özerk değildirler; daha ziyade diğer kavramlarla - ama farklı teorik geleneklere göre değişerekbağlantılanırlar. Dolayısıyla, “ideoloji” Marx’ın icadı değilken, bugünkü kullanımında Marksist gelenekle yakından ilgilidir ve modern Batı Marksizmi’nin geniş problematiği olarak tanımladığımız, tahakküm ve tabiiyet ilişkilerinin doğrudan zora, asgari düzeyde, başvurularak nasıl yeniden üretildiğini anlama çabasının içerisinde yer alır. Öte yandan "söylem", dilin ve diğer toplumsal göstergebilim biçimlerinin toplumsal deneyimi aktarmanın ötesinde toplumsal öznelerin (öznelliklerin ve bununla bağlantılı kimliklerin), özneler arasındaki ilişkilerin ve var oldukları alanın oluşturulmasında oynadığı önemli rolü kavramamıza yardımcı olan terimi sunmakla, modern sosyal teorideki dilsel dönemeçte yer alır ve önemini bu dönemeçteki merkezî rolünden alır.

$\mathrm{Bu}$ çalışmadaki ilgilerimiz açısından ideoloji ve söylemi birbirinden ayrıştırırken bakmamız gereken teoriler, maalesef, birbirine yaklaştırarak kıyaslayıp, karşılaştırabileceğimiz sabit ve istikrarlı teoriler değiller. İlerleyen sayfalarda da göstereceğimiz gibi ideoloji ve söylemin içerisinde yer aldıkları teorik geleneklerin, kadim buzullara benzer şekilde, birbirlerine doğru acımasızca kayıyor olmaları, yapmak istediğimiz şeyi daha da zorlaştırıyor. Buzul analojimize tutunan bazı yorumcular iki kavramın, az çok barışçıl bir şekilde birleştiklerini, dolayısıyla kavramsal aygıtlarının artık birbirlerinin yerine kullanılabileceğini varsayageldiler. Diğer yorumcular ise daha yıkıcı bir senaryoyu benimsediler ve iki geleneğin, aralarından biri arkasında bıraktığı entelektüel enkazda seyrinden sadece küçük izler bırakacak şekilde parçalanana kadar sert ve uzun bir savaş vermek zorunda olduklarını varsayageldiler.

$\mathrm{Bu}$ yazıda iki farklı geleneğin entelektüel tarihini anlatmıyoruz. Bu yaklaşımı reddediyoruz; ya da daha doğru bir ifadeyle bu yaklaşımdan kaçınıyoruz. Bunun nedeni “fikirler tarihi” olarak adlandırılan projenin, kendi içinde tartışmalı olacak ölçüde yorucu ihtilaflarla yıpranmış olmasından ibaret değil. Aslında daha sıradan ve yeteneklerimizin 
sınırlarını ve elimizdeki projenin kapsamının sınırlarını gösteren nedenlerimiz var. Daha hırslı herhangi bir amacın yerine bu yazıyı semptomatik olarak adlandırılabilecek üç incelemeye girişerek örgütleyeceğiz. İlk olarak, ideoloji kuramı geleneğine bakacağız. Bunu, modern Batı Marksizmi içinde ideoloji üzerine yapılan tartışmaları inceleyerek yapacağız. Jorge Larrain'in Marksist gelenek içerisinde negatif ve pozitif ideoloji kavramsallaştırması arasında yaptığı cazip ayrımın tetiklediği artık genişlemiş olan tartışmaya gireceğiz (Larrain, 1983). Ardından, Michel Foucault'nun ayrıntılı bir şekilde tasarladığı söylem teorisini inceleyeceğiz. Üçüncü çalışma konumuz, iki geleneğin Ernesto Laclau ve Chantal Mouffe'un eserlerinde ortaya çıkan ve söylemle ideoloji arasında bir kopuşa meyleden—bir noktada birleştirici ya da yıkıcı — temasıyla ilgili olacak. Bu çözümü Stuart Hall'un savunduğu— bizim önerdiğimiz yaklaşıma en yakın duran—ve söylem teorisinin sunduğu açılımlardan yararlanırken ideoloji kavramından vazgeçmeyen Gramscici konumla karşı karşıya getireceğiz. Böyle seçim yapmamızı, çalışmamızın semptomatik olduğunu iddia ederek de işaret ettiğimiz gibi, bu yaklaşımların kendi içlerinde oldukça etkili olmalarının yanı sıra ideoloji ve söylem betimleriyle birbirleriyle çelişen bir şekilde iştigal ediyor olmalarıyla gerekçelendiriyoruz. Bu eserlerin incelenmesi sayesinde, nihai bir karara ulaşamasak da alternatif gelenekler arasında potansiyel olarak üretken bir alışveriş önerisi getirme firsatını yakalayacağız.

Bu incelemelere kalkışmadan önce bakmamız gereken başlangıç mahiyetinde iki konu var. İdeoloji ve söylem arasında, kullanışı, ama geçici bir ayrım sunarsak okurlara yardımcı olabileceğimizi düşünüyoruz. Bunu yaptıktan sonra teorik konumumuzun genel çerçevesinin bir taslağını vereceğiz-diğer bir ifadeyle, teorik konumumuzu savunmak yerine açıklayacağız.

\section{Ön Hazırlıklar}

İdeoloji ve söylem kavramları arasında geçici de olsa şöyle bir ayrım öneriyoruz. “İdeoloji” kavramı, genelde, Marx'dan tefsirle, bilinç biçimlerinin insanların çatışan çıkarları hakkında bilinçlenip bu çıkarlar üzerinden mücadeleye girmelerini nasıl etkilediğini belirlemekle ilgilenen araştırmalarda karşımıza çıkar. ${ }^{1}$ Dolayısıyla ideoloji, "çıkarlar" ve "bilinç biçimleri”" arasında belirli bir bağlantının olduğunu imler. Çıkarların, tecrübe edilme biçimlerinden ayrıştırılabilir şekilde tanımlanabilecekleri kanaati böyle bir anlayışın merkezinde yer alır.

Öte yandan söylem söz konusu olduğunda, bütün toplumsal ilişkilerin, bu ilişsilere katılanların düşünüşlerini, anlayışlarını ve tecrübelerini düzenleyen özgül dilsel ya da 
göstergesel araçlar itibariyle yaşandıkları ve kavrandıkları yönündeki argümana bağlı olarak dikkat, toplumsal ilişkiler içerisindeki bağlantı koşullarına odaklanır. "Söylem" kavramı, bir varoluş biçimi olarak söylemin, söz gelimi çıkar nosyonlarının çağırdığı ve yaşanmış tecrübenin söylemsel içeriğine dışsal olan unsurlarla bağlantılı olup olmadığı konusunda bilinçli bir şekilde tarafsız ya da şüphecidir.

Burada, resmettiğimiz ayrımın ideolojinin ya da söylemin ne "olduğu"nu söyleme çabasında olmadığını belirtmemiz gerekiyor. Tanımlardan ziyade bir ayrım sunmaya çalıştık. Söylem ve ideolojiyi birbirinden ayıran bütün farklılıkları haritalandırmak yerine genel bir ayrımın kısa bir versiyonunu önermek niyetindeyiz. Hem "söylem" hem de "ideoloji", iletişimsel pratikler vasıtasıyla dolayımlanan toplumsal eylem alanının geneliyle ilgili açıklamalarda yer buluyorsa, "söylem" bu pratiklerin içsel özelliklerine, özellikle dilsel ve

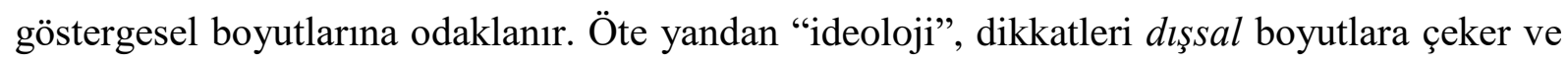
yaşanmış tecrübenin, temelde ondan ayrıştırılabilen çıkar ve konum nosyonlarıyla nasıl bağlantılandığına odaklanmamızı sağlar.

İçsel/dışsal ayrımının belirli bir versiyonuna bağlı kalmamız felsefî realizmin bir versiyonuna-yumuşak realizm olarak adlandıracağımız bir versiyonuna-entelektüel bağll1ık gerektirir. Bir yandan (büyük "H”yle) "Hakikat"i reddederken, öte yandan öznel tercihlere indirgenemeyecek olan (küçük "h”yle) "hakikat”e ve ilgilere tutunmamızı mümkün kılan bir felsefî çerçeve arıyoruz. Felsefi olarak işe yarar bir konum önereceğimizi iddia etmiyoruz; daha ziyade betimsel olarak Richard Bernstein'in "nesnelcilikle görececilik arasında" (Bernstein, 1983) olarak nitelendirdiği "ü̧̈üncü yolcu" konuma yakın duruyoruz. Yumuşak realizmimizin "yumuşaklığı”, bilgi iddalarının hiçbir zaman doğrulanamayacağı ve hakikat iddialarını doğrulayabilecek, söylemin dışında kalan bir bakış açısı olmadığı yönündeki post-modern argümanı baştan kabul etmemizden kaynaklanıyor. Konumumuzu realist kılan ise bilginin, "daha iyi” bir açıklamayla yerinden edilmeye her zaman açık olduğu için yanlışlanabilirliğin ötesine geçemese de, bilinebilir bir söylemsel olmayan alanın olduğunda 1srar etmemizle bağlantıll.

Geri kazanma projemizin "Üçüncü Yol”un teorisini oluşturmaya yönelik genel arayışımızın bir parçası olduğunu düşünüyoruz. Böyle bir bakış açısı, bugün post-modernizm adı altında toparlanan ve bilinebilir ve nesnel bir gerçekliği kavrama isteğini artık bırakmak ve Aydınlanma'dan herhangi bir iz taşıyan entelektüel ya da siyasal projelerin hepsinden vazgeçmek zorunda olduğumuzda ısrar eden felaket senaryolarını reddeder. Üçüncü Yol, daha ziyade, post-modernizmin nesnelci epistemoloji ve temsilî dilsel yaklaşımları temelden sarsan 
duruşunu ciddiye alır. Bu açıdan, ideoloji teorisinin geleneğini tamamlamak ve hattâ daha da geliştirmek umuduyla söylem teorisiyle ilişkileniyoruz.

\section{İdeoloji: Eleştirel mi, Toplumsal mı?}

Marx’ın ideoloji teorisi üzerine çalışmasında Jorge Larrain, pozitif ve negatif ideoloji anlayışları arasında ayrım yapar. "Negatif" olan, çarpıtılmış düşünceye işaret eder; "pozitif" kavramsallaştırma ise toplumsal bilincin inşasına odaklanır. Larrain, genel anlamda, Marksist ideoloji teorisinde pozitif versiyonun ağır bastığını, ancak, negatif versiyonun Marx'ın düşüncesinin en eleştirel eşiğini oluşturduğunu ileri sürer.

[İ]deoloji kavramının eleştirel ve negatif yananlamları (...) her zaman için, çelişkili ve tersyüz edilmiş bir gerçekliğin gizlenmesi ya da çarpıtılmasıyla bir şekilde bağlantılı olan özel bir hatanın eleştirisi için kullanılır. [İdeoloji] $\mathrm{Bu}$ nedenle hem sınırlı hem de tarihsel bir kavramdır: Sınırlıdır, zira her çeşit hatayı kapsamaz ve egemen olan bütün fikirleri etkilemez; tarihseldir; zira, çelişkilerin evrimine dayanır (Larrain, 1983: 42).

Larrain'e göre, negatif versiyon, ideolojinin sırf yanılsama olarak alındığı bir bakış açısını içermek durumunda değildir. Benzer şekilde, ideolojinin "yanlış bilince" indirgenmesini beraberinde getirmez. Marx'ın ideolojiye yaklaşımındaki eleştirel boyut, Marx'ın ifadesiyle — tâbi kılınmış sınıfların ürettikleri fikirlerin egemen maddi ilişkileri ve bağlantılı çıkarları ifade ettikleri ve yeniden ürettikleri- “gerçek yaşamın dili” olarak tanımlanan olguya odaklanmasından kaynaklanır. Larrain Marx’ın ideoloji anlayışını yanlış temsil teorisi olarak okur: "İdeoloji, çelişkilerin doğru olmayan ya da çarpıtılmış bir resmini çizen belirli bir bilinç biçimidir. Bunu, çelişskileri yok sayarak ya da yanlış temsil ederek yapar" (1983: 42).

İdeoloji anlayışının “negatif” versiyonunun en açık şekilde Alman İdeolojisi’nde irdelendiği söylenebilir. Bu eserde, Marx terimi "erkeklerin [sic] ve ilişkilerinin, camera obscura'da olduğu gibi başaşağı" ${ }^{2}$ bir şekilde "yaşam süreçlerinin yansıları ya da yankıları" ya da "hayaletler olarak görünmeleri”yle ilişkili olarak kullanır (Marx ve Engels, 1976: 36). $\mathrm{Bu}$ kullanımların hepsindeki ortak hat, toplumsal gerçekliğin mistifikasyonu, yanlış alg1lanması ya da "eksik" bilgisidir.

Larrain'in ayrımına bir şeyler eklemeyi öneriyoruz. Düşüncenin tamamıyla toplumsal olarak inşa edildiği yönündeki-doğru ama yetersiz olan—genel argümanın ötesine geçen bir ideoloji kavramsallaştırmasını vurgulayacağız. İdeoloji kavramı bu yaklaşıma, ideolojininhep birilerini kayıracak ve diğerlerine zarar verecek şekilde işlemesi anlamında—bir yön 
belirleme kapasitesi sergilediği savını ekler. Dolayısıyla, tâbi kılınmış sınıfların ve toplumsal grupların yaşanmış tecrübelerinden çıkan bilinç biçimlerinin mevcut toplumsal ilişkileri nasıl desteklediği ve böylelikle bu sınıfları ve grupları bağımlılıklarının doğasını açığa çıkaran bilinç biçimlerini geliştirmekten nasıl alıkoyduğunu açıklamak, bir ideoloji teorisi açısından çok önemli bir amaç teşkil eder. İdeoloji, en basit ve yaygın biçimiyle, mevcut toplumsal ilişkileri hem doğal hem de kaçınılmaz olarak sunar; tikel çıkarlar özgül yerlerinden kopartılırlar ve evrensel ve yansızmış gibi görünürler.

İdeolojinin yön belirleme kapasitesine sahip olduğu fikrini dâhil etmemiz için—sırf negatif-pozitif ayrımı çok fazla değer yüklü göründüğü için bile olsa- Larrain'in terminolojisinde değişiklik yapmamız gerekiyor. Ama daha da önemlisi, "eleştirel” ve "sosyolojik" nitelendirmelerinin argümanımızın gücünü anlamak açısından daha uygun olduğunu düşünüyoruz. Eleştirel ideoloji yaklaşımı, toplumsal bilginin ve tecrübenin inşa edildiği alanın sınırlarını çizerken, tâbi kılınmış sınıfların ya da baskı altındaki grupların durumunu, koşullarını ya da tecrübesini "mistifiye" eder. Dolayısıyla, ideolojinin toplumsal etkilerine ya da sonuçlarına odaklanır. Buna bağlı olarak, ideoloji kavramını en isabetli şekilde kullanabilmenin yolunun “ideolojik etkiler”i belirlemek olduğunu önerebiliriz. $\mathrm{Bu}$ bakış açısının, Marx'ın optik camera obscura metaforunda oldukça belirleyici bir yere sahip olan olumsuzlamanın ya da geriye döndürmenin sonuçlarına yol açmadığını vurgulamamız gerekiyor.

İdeolojiyi sosyolojik temelde kavramsallaştırmak, onu sınıfların, grupların ya da aktörlerin özgül toplumsal konumlarının bir çıktısı ya da sonucu olarak gören çoğul ideoloji anlayışına odaklanır. Buna göre, ideoloji nesnel toplumsal konumun bir sonucudur. En önemlisi, bir mücadele alanı ya da meydanı olarak rekabet halindeki “ideolojiler”in çokluğu nosyonunun teoriye dâhil edilmesini sağlar. Ancak, her bir toplumsal sınıfın kendi özgül “ideoloji”sini ifade ettiği yönündeki argümanı barındıran bir tekabüliyet anlatısına işaret etmez. Böylelikle, rekabet halindeki ideolojilerin çoğulluğu belirli bir toplumsal konum ve nesnel çıkarlar anlayışıyla bağlantılandırılır. Bu sosyolojik çerçevede ideoloji, kurgusal ya da aldatıcı değil, "gerçek" ya da maddidir. Bu nedenle de, engellenemez; zira insanların içerisinde var oldukları ve toplumsal yaşamlarını sürdürdükleri anlamlar ve değerler çerçevesini tanımlar.

"Pozitif" ya da "sosyolojik" olarak adlandırmayı tercih ettiğimiz bu yaklaşım Batı Marksizmi’nde önemli bir yer kaplayagelen, ideoloji teorisinin açımlanması amacı için önemli bir araç sunar. Bu yaklaşım, toplumsal ve ekonomik mücadelelerin verildiği fiilî şartlara daha yakından bakmayı gerektirir. Öte yandan, bu ikinci versiyonun değeri açık olsa 
da, eleştirel ideoloji kavrayışını arka plana atma ya da marjinalize etme gibi niyet edilmemiş bir sonucu olduğunu ileri süreceğiz. Sosyolojik versiyonun bugünkü Marksistler açısından öncelikli olmasının önemli bir boyutu, ideoloji ve söylem kavramları arasındaki çizgiyi bulanıklaştırma ya da bu iki kavramı birbiriyle karıştırma eğilimidir. $\mathrm{Bu}$ ideoloji kavramsallaştırmasından — “yaşanmış tecrübe”nin aracı olarak—vazgeçmeden daha önceki "negatif" ya da bizim tercihimizle eleştirel gelenekten bir şeyleri ideoloji kavramsallaştırmasına yeniden dâhil etmenin hem mümkün hem de cazip olduğunu düşünüyoruz.

Marx'ın, ideolojinin mistifiye edici özelliklerine başvurmasındaki birincil sorun "hakikat"/“sahtelik" ekseninde inşa edilmiş bir epistemolojik varsayımlar kümesine dayanmasıdır. En aşırı biçiminde bu, Marx sonrası Marksizm'nde epey yaygın olan güvenilmez "yanlış bilinç” nosyonunun ortaya çıkmasına yol açar. Marx’1 hakikat/sahtelik ayrımına özgü rasyonalizmden kurtarmak amacıyla negatif ya da eleştirel ideoloji anlayışından vazgeçmek, hiç şüphesiz kolay olurdu. Ama aynı zamanda, "mistifikasyon" tezinin önemli ve kritik bir potansiyele sahip olduğunu, bu nedenle vazgeçilmemesi ve geliştirilmesi gerektiğini ileri sürüyoruz.

Marx'ın eleştirel ideoloji anlayışını makul bir biçimde elimizde tutmaya çalışmanın önemli olduğunu düşünüyoruz; zira bu anlayış “söylem”e indirgenemez bir ideoloji kavramını mümkün kılıyor. Böyle bir tasvir, Marx ideoloji anlayışını akıl/varlık ayrımı bağlamında kurmuş olsa da, ideoloji anlayışının "fikirler” ya da "düşünmek”le alâkalı olmadığında ısrar etmeyi beraberinde getirir. İdeoloji, “düşünme” alanından ziyade, yaşanmışın ya da tecrübe edilmişin alanıyla bağlantılıdır. ${ }^{3} \mathrm{Bu}$ argümanı oluşturmak için başvurulan önemli bir örnek “ortak kanı” nosyonundan çıkar. Ortak kanının "kendiliğinden olma” niteliği, şeffaflığı, doğallığı, üzerine temellendiği öncüllerin incelenmesini reddedişi, düzeltilmeye olan direnci, anında fark edilir olması onu hem "deneyimlenen", hem "kendiliğinden” hem de bilinç dışı k1lıyor. Ortak kanının içerisinde yaşıyoruz, onu düşünmüyoruz.

\section{Marx ve Dil: Eksik Boyut}

Sosyal teori yirminci yüzyılda dile ve iletişimsel etkileşime yönelik ilgide yükselişe sahne oldu. Dilbilim, göstergebilim, semantik ve daha genel olarak söylem teorisi sosyal ve felsefî̀ düşüncede merkezî konuma yerleştiler; bu çağın önde gelen entelektüellerinindiğerlerinin yanı sıra Wittgenstein, Habermas, Chomsky ve Foucault'nun-eserlerinde ana temalar olageldiler. Raymond Williams'ın belirttiği gibi "Marksizm bizatihi dil üzerine düşünmek açısından pek katkı sunmamıştı" (Williams, 1977: 21). 
Marx'ın dile yaklaşımındaki eksikliklerin büyük bir bölümü Marx'ın eserlerini ürettiği felsefî̀ bağlamdan kaynaklanır; idealizm ve materyalizm arasında kurduğu her şeyi kapsayıcı çatışma ve materyalizme bağlılığı sonucunda ağırlıklı olarak vurgulanan konu toplumsal yaşamın maddi kabuğu olmuştur. Buna paralel olarak, akılla ilgili ya da düşünsel olan boyutlara şüpheyle yaklaşmıştır. Böylelikle, toplumsal öznelerin kurulumunda üretken emeğin rolünün üzerinde durması, Marx'ın felsefî materyalizminde zaman zaman fizikalist bir çizgi olarak açığa çıkan bir yaklaşıma yol açmıştır. Öte yandan ilginç bir şekilde, Marx dil sorunu hakkında tamamen sessiz kalmamıştır; Alman İdeolojisi'nde dilin önemini eleştirel—ancak oldukça kısa bir şekilde-kabul ettiğini görürüz. Dil, toplumsal olanın asli unsurlarından biri, dört asli kesitinden biri olarak görülür. Williams'ın Marx’tan özetlediği gibi,

$\mathrm{Bu}$ birincil madde üretiminin insana özgü biçimi üç açıdan tanımlanmıştır: Gereksinimler, yeni gereksinimler ve insani yeniden üretim.... Gelişmeye özgü insansallık ise dördüncü "açı"ya bağlı olarak tanımlanır: Üretim de başından itibaren toplumsal bir ilişkidir. Buna bağlı olarak, pratik bilinçlilik anlamında dil, başlangıcından itibaren [üretimin] vazgeçilmez bir bileşenidir (Williams, 1977: 29-30).

Öyleyse, Alman İdeolojisi'nde dil, üretime ikincil kılınmaz, aksine, toplumsalın özgüllüğünü tanımlayan her şeyle zorunlu olarak eşzamanlı bir olgu olarak karşımıza çıkar.

Söylem teorisini Marx'ın ideoloji teorisinden ayıran unsur, Marx'1n teorisinin, eylem ve bilinç ikiliği etrafında kurulan bir eylem teorisinden kökleniyor olmasıdır. Söylem teorisi, eylem teorisinden kopuşa işaret eden ve toplumsalın "dilsel kurulumu"nun merkezîliğine odaklanan dilsel dönemecin başat sonuçlarından biridir. Dolayısıyla, iki anahtar kavramımız birbirinden kökten farklılıklara sahip epistemolojik stratejilerden çıkarlar; aralarında süreğen bir gerilim vardır. Buradaki temel sorumuz, bu gerilimin verimli bir şekilde kullanılıp kullanılamayacağıdır.

Öyleyse denebilir ki dil, Marksizm'de tamamen yok sayılmaktan ziyade, periferde bir role sıkıştırılmıştır. Raymond Williams'ın çalışmaları vasıtasıyla, kültür, özellikle özgül olarak roman biçimindeki haliyle, eleştirel teorinin ilk dalgasında ve ardından İngiliz Marksizmi merkezî bir konumdaydı (Williams, 1977; 1980). Ardından, Habermas'ın, Marksist geleneğin sınırlarında seyreden uzun yolunda "iletişim" merkeze oturdu.

Burada asıl önemli olan, Marksizm'de gelişmiş bir dil kuramsallaştırmasının olmaması değil, yerel(leştirilmişs) bir teori geliştirmeye başlanırken her şeyi kapsayıcı "üstyapı” kavramı dışında uygun bir ad bile bulunamamış olmasıdır. Bu eksikliğin ancak post-yapısalcı sosyal teoriden çıkan doğrudan meydan okumayla görünürlük kazanması Marx'ın temel/üstyapı metaforunun temel ve kendi içinde sınırlayıcı etkisinin de beyanı olduğu söylenebilir. 
“Üstyapı” kavramının dayattığı kör nokta büyük ölçüde, sadece dili, iletişimi ve kültürü değil aynı zamanda, devlet ve siyasal kurumların kurumsal ağını da içine alacak şekilde yayılan, aşırı içerimleyiciliğinden kaynaklanır. Üstyapı kavramı, üretimin dışında kalan olguların neredeyse tümünün, farkında olunmadan olsa da, havale edildiği artık bir kategori işlevi göregelmiştir.

Marksizm'in teorik krizinin pek de, ekonomizminden, indirgemeciliğinden ya da belirlenimciliğinden kaynaklandığı kanaatinde değiliz. Daha ziyade, bütünü kapsayıcı bir sosyal teori sunma amacının altında yatan "üstyapı” kavramının artık doğasının Marksist teoriyi bu tür farklı toplumsallık biçimleri için depo işlevi görmeye ittiğini ve meydan okumalar karşısında kendisinden beklediğimiz uygun kavramları oluşturamayacak ve açıklamalar sunamayacak hale getirdiğini düşünüyoruz. Mesele, sadece altyap1- üstyapı imgeleminin bizlere kısıtlayıcı metaforik bir kapsam sunuyor olması değildir. Daha ziyade, bu imgelemin -tek yanlılığı, bu tek yanın (ekonomik temel) gelişmişliği ve zenginliğinin, dışarıda kalanların tamamını sınırlı, birbirine geçmiş ve gelişmeye tamamen kapalı halde bırakmasıdır. Ekonomizmin, indirgemeciliğin ve belirlenimciliğin kusurlarının en belirgin sonucunun, ekonomik ilişkilere ve pratiklere tek yanlı bir şekilde odaklanılmasından ziyade insan toplumsallığının diğer birçok görünümlerine uygun bir teorileştirmeyi sekteye uğratmaları ve hattâ dışarıda bırakmaları olduğunu söylemek mümkündür.

Batı Marksizmi’nin akışı içinde Marx’ın mirasındaki tek yanlılık bertaraf edilmeye çalışılmıştır. Bu hattı açımlamak için Louis Althusser'in önemli müdahalelerini kısaca yeniden gözden geçiriyoruz.

\section{Althusser ve Söyleme Doğru Açılım}

Batı Marksizmi'nin patlamasında Louis Althusser'den daha büyük etkisi olan bir isim yoktur. Müdahaleleri teorik titizlik ve sofistikasyon için yeni standartları beraberinde getirmiştir. Çalışmaları bir yandan yenilikçiyken diğer yandan Marksizm içinde “ortodoksi”ye bağlılığı devam ettirmeye yönelik derinden bir isteğin varlığını gösterir. Yapısalcılığa karşı duruşun genel olarak yükselişe geçişiyle birlikte Althusser'in argümanlarının gözden düşmeye başladığı bir dönemde, içgörülerinin birçoğunun, özellikle ideoloji üzerine süregiden tartışmalarda merkezî önemlerini korudukları söylenebilir.

Althusser'in ideolojiye yaklaşımını, Larrain'in negatif ve pozitif ideoloji kavramsallaştırmasına referansla ele alacağız. Althusser ideoloji ve bilimi birbirinden ayırmak vasıtasıyla negatif ideoloji kavrayışının bir versiyonunu sunar. Buna göre, ideoloji, kusurlu, ham ve bu nedenle defolu bilgi olarak görülür. Bilim, kuramsal pratik vasitasıyla 
dönüştürülmüş hakiki bilgi olarak görülür. Böyle bir yaklaşımın iki sonucuna değinmek gerekir: İlk olarak, Althusser'in ilgileri, hakikat/sahtelik ikiliği üzerinde temellenen epistemolojik geleneğin içinde yer alır; ikincisi, Marx’ın “idealar” sorunsalını devam ettirir ki bu, açık bir şekilde, az çok tamamlanmış düşünce sistemleri olarak "teorik ideolojiler"e odaklanma eğiliminde karşımıza çıkar.

Pozitif ya da sosyolojik ideoloji kavrayışında ise, ideolojinin "yaşanmış tecrübe" olduğunu düşünen oldukça farklı bir Althusser'le karşılaşırız. Althusser bu çerçevede, ideoloji içinde ve vasıtasıyla kurulan özneler anlayışını geliştirir. Buna göre ideoloji, birbirine muhalif sınıfların ideolojik ya da rakip ideolojik formasyonlar içerisinden birbirleriyle çatışmaya girdikleri ya da çatışmalarını ifadelendirdikleri bir alandır.

$\mathrm{Bu}$ çalışmadaki argümanımızla özellikle alâkalı olan konu, Althusser'in çalışmalarındaki negatif ve pozitif ideoloji kavrayışıdır. İdeolojiler üzerine yürütülen çalışmalar alanına yaptığı en önemli katkı, ideolojinin insanları özneler (öznel(1)ik + tabiiyet) olarak kurduğu mekanizmaya işaret eden "çağrılma" kavramıdır. Daha açık bir ifadeyle, bu çalışmadaki argümanımız açısından en önemli olan nokta Althusser'in ideoloji/bilim ikiliğini-ham (defolu) bilgi karşısında saf (eksiksiz) bilgi-muhafaza etmesiyle bireylerin ideoloji vasıtasıyla "çağrılma"ları ve böylelikle özneler olarak kurulmaları nosyonu arasındaki bağlantıdır. $\mathrm{Bu}$ noktada, çağrılmanın temel özelliğinin muktedir “öteki” tarafindan “seslenilmek"ten (Althusser'in örneğinde polisin yayaya "hey sen" diye seslenmesinden) ibaret olmadığını, çağrılan öznenin bu çağrıyı ikrar sürecinin de-ki, ikili tabiiyet-öznellik mekanizmasını açığa çıkaran bir ikrardır-bunun kadar önemli olduğunu ileri sürüyoruz (Althusser, 1971: 174).

Althusser'in, ideoloji-söylem ikilisinin işaret ettiği ayrıma yaklaştığı yönündeki bir okumanın mümkün olduğunu ileri sürüyoruz. Althusser, ideolojinin maddiliğinde ısrarla işe başlıyor; ama burada önemli bir kayma var: $\mathrm{Bu}$, en basit haliyle, bireylerin ve pratiklerinin içerisinde "fikirler”in üretiminden “özneler”'in üretimine doğru gerçekleşen bir kaymadır. Öte yandan, Althusser'in çalışmalarında eksik olan, bireylerin yaşanmış mevcudiyetlerinin salt “yansıması"na indirgenemeyecek maddi pratikler olarak dilsel pratiğin gelişmiş bir kuramsallaştırmasının bulunmamasıdır. Bu kesinlikle önemli bir bileşendir; zira bu boşluk doldurulmazsa pratiğin temelleri ancak üretim ve yeniden-üretim faaliyetlerinde - diğer bir ifadeyle, indirgemecilikte-bulunabilir: Bu tam da, Althusser'i Marksizmi kurtarmak için harekete geçiren kusurdur.

Althusser'i, çalışmalarının ötesine geçerek okumak istemiyoruz. "Seslenilme” olarak “çağrılma" imgeleminin metaforik kullanımı — diğer bir ifadeyle, sözel olarak seslenilme ve 
böylelikle, "çağırılma" karşısında kendi ikrarımız/reddimiz vasıtasıyla toplumsal özneler olarak kurulmamız-Althusser'in yaklaşımının merkezinde durur. Çağırılma "seslenilme"den fazlasını yapar: Özneleri, özgül söylemsel bağlamlarda konumlandırır ya da yerleştirir. Örneğin, "endişeli ebeveynler"in "satanik tarikat”ların çocuk istismarındaki rolleriyle ilgili kaygılarını dile getiren politikacı, sadece ebeveynlikle, ebeveynliğin sorumlulukları ve endişeleriyle ilgili bir dizi normatif önvarsayımı kullanıma sokmakla kalmaz, aynı zamanda çocuk istismarının oldukça rahatsız edici bir gerçekliği olan "normal” ebeveynliğin pek tanıdık pratikleri açısından hem gizemli hem de şeytani olan dışsal bir nedenselliği de araya ekler. Ya da, “sıradan vergi mükellefi”nin çağırılması, vergi mükelleflerini motive ettiği varsayılan ve siyasal muhakemede bencilliği öven ve "refah beleşçileri”ne ve diğer istenmeyenlere karşı muhalefet ihtimalini kuran siyasal hesap biçimleri hakkında bir dizi söylemi kullanıma sokabilir. Diğer bir ifadeyle, çağırılmanın, sırf “seslenilme”nin karşılıklı ikrarından daha fazla şeyi gerektirdiği göz önüne alınmalıdır; bunun ötesinde öznelerin ve özne konumlarının hem kuruldukları hem de değiştirildikleri daha karmaşık süreçler yer alır.

Althusser'in çağırılma teziyle söylem kavramı arasındaki doğrudan bağ göz ardı edilemeyecek kadar önemlidir. Althusser'in ideoloji kavrayışının bu boyutunu, sosyolojik ideoloji teorisi olarak tanımlamak yanlış olmayacaktır—bu, aşağıda daha detaylı bir şekilde tartışacağımız gibi, söylem teorisiyle tamamen uyumludur. Stuart Hall, Althusser'in yapmayı başardığı şeyi iyi anlamıştır.

Althusser'in [ideoloji teorisinde yaptı̆̆ 1 revizyonlar (...) ideolojiye "çarpıtılmış fikirler" ve "yanlış bilinç" [temelli] yaklaşımdan kesin bir uzaklaşmayı destekledi. Bu, daha dilbilimsel ya da "söylemsel" bir ideoloji kavrayışının yolunu açtı. Tamamen göz ardı edilmiş bir mesele olan, ideolojinin nasıl içselleştirildiği, nasıl "kendiliğinden" konuşmaya başladığımız sorularını gündeme aldı (Hall, 1983: 64).

Böyle bir, "söylemsel ideoloji kavrayışı" toplumsalın ve toplumsal öznelerin kurulumunda söylemin rolünü görmeye yaklaşmamızı sağlayacak bir şekilde Althusser'i yeniden-okumayı mümkün kılar.

Şöyle bir Althusser okuması yapıyoruz: Bireyler, söylem vasıtasıyla özneler olarak çağırılırlar; ideoloji, söz konusu söylemler vasıtasıyla kurulan toplumsal kategorilerin (sınıflar, gruplar, vb.) çıkarlarını ifadelendirmekte yetersiz kalan belirli söylem biçimlerini temsil eder.

$\mathrm{Bu}$ tanımla benimsediğimiz konumun siyasal kökenlerini belirtmemiz gerekiyor. Öznelerin kurulum ve yeniden konumlandırılmalarında aracı olan söylemsel pratikler ideolojik etkilere yol açabilirler — ama bu zorunlu değildir. Bu söylemsel pratikler, pozitif 
alternatiften negatif redde_- “çağırılma"yı düpedüz reddeden ve bu vesileyle tanımlanmaya karşı duran "tersliğe" - kadar uzanan bir çeşitlilik içinde potansiyel çatışma alanları olarak var olurlar. Birbirinden ayrı duran ve dağınık söylemsel öğeleri, birleşik popüler toplumsal hareketler içinde birleştirme amacını taşıyan "söylemsel alanlar" açmak her zaman mümkündür. $\mathrm{Bu}$ alanların, potansiyel etkileyicilikleri sayesinde önceden egemen olan söylemleri sarsan ve yeni destekçiler kazanan alternatif söylemlerin dile getirilmesini sağlamaları-diğer bir ifadeyle, Gramsci'nin karşı-hegemonya projesini ilerletmeleriihtimal dahilindedir.

\section{Söylem Nedir?}

Marksist ideoloji teorisinin geçirdiği değişimlerle ilgili anlatımızda dikkate değer teorik sınırlılıkların yanı sıra sorgulanamaz bir potansiyelin altını çizdik. "Söylem” kavramına bu kusurları bertaraf etme ve söz konusu potansiyeli hayata geçirme misyonu yüklenmiştir. Başlangıçta, ideoloji ve söylem arasına geçici bir ayrım çizgisi çektik. Söylem teorisi, dünyanın zihinsel ve maddi olarak iki büyük alana ayrılarak düzenlenmesini sarsmayı gerektirir. Kavram, sosyal bilimler tasarısının felsefî arka planını oluşturan karşıtlıklarındoğa/kültür, birey/toplum ve akıl/beden-büyük üçlemesi kapsamındaki düşünce/varlık karşıtlığının nüfuz edici etkisinden kaçış ihtimalini sağlar. Toplumsallığın tanımlayıcı özelliği ve koşulu olarak dille işe başlamak bu nüfuz edici ikiliklerde bir yarık yaratmanın dikkat çekici yollarından biridir. Bu, "toplumsal"1, salt bireyler yekûnundan ayrı olarak düşünmek için basit bir yöntem sunar.

Söylem teorisini anlamak için başvurulacak en uygun araç, onu, türlerin toplumsal tarihinin birincil özellikleri içinde "toplumsal"dan ne anladığımızı temellendirmeye yönelik bir çaba olarak görmektir. Başlangıç noktası olarak dilin ise ayrı bir avantajı vardır; hem zaman içinde devamlılık hem de geniş bir çeşitlilik arz eder; böylelikle, türlerin kendine özgü toplumsal yanını niteleyen genelliği ve özgüllüğü örnekler. Burada dilbilim teorisi içerisinde yer alan çeşitli akımların, bugün söylem teorisindeki farklı akımları nasıl oluşturduklarını gösteren bir entelektüel tarihin izini sürmek niyetinde değiliz. Sadece, söylem teorisinin, başlangıç niteliğinde ve teknik olmayan bir haritasını sunmak istiyoruz. Daha sonra bu haritayı, açıkça ideoloji teorisine alternatif olduğu düşünülen söylem teorisinin Michel Foucault'nun eserlerindeki rolünü incelemek için kullanacağız.

Söylem nedir? "Söylem” dil ya da sözel olmayan işaret sistemleri vasıtasıyla kurulan toplumsal iletişim ağlarına işaret eder. Temel özelliği, birbirleriyle bağlantılı bir işaretler sistemini devreye sokmaktır. Nispeten önemli örnekleri, konuşma sistemleri ya da yazılı 
dilken (metinler), söylem sözel olmayan işaretler sistemi halinde de karşımıza çıkabilir: Örneğin, erkeklerin kadınlar için kapı açmaları, kadınlar odaya girdiklerinde ayağa kalkmaları vb., düzenleyici çerçevesini kadınların hem ikincil bir konumda oldukları hem de erkekler tarafından itina gösterilmeye ve korunmaya ihtiyaç duydukları keskin bir cinsel iş bölümünün oluşturduğu bir söylemin bileşenleridir.

Stuart Hall'a göre söylemin genel tanımı şu şekilde yapılabilir: "Dil vasıtasıyla görünürlük kazanan ve düzenlenen, hazır ve önceden kurulmuş 'tecrübe edişler' kümesi' (1977: 322). Bu kavramla, insanların söylem içinde yaşadıklarına ve deneyimlediklerine işaret edilir. Daha açık bir ifadeyle, söylemler, neyin tecrübe edilebileceğini ya da tecrübenin taşıyabileceği anlamı sınırlandıran ve dolayısıyla, söylenebilecek ve yapılabilecek olanı etkileyen çerçeveler dayatırlar. Her bir söylem, bazı şeylerin söylenmesine izin verir ve diğer bazı şeylerin söylenmesini zorlaştırır ya da engeller. Söylemler böylelikle iletişimsel eylemin gerçekleşmesini sağlayan özgül ve ayrıştırılabilir vasıtalar sunarlar.

Buradaki temel epistemolojik varsayım dilin, konuşmanın ve yazmanın hiçbir zaman tamamen göndergesel olamayacağı kanaatidir. Bu tartışma birçok şekilde sürdürülebilir; ama Saussure'e başvurmak muhtemelen an faydalı yol olacaktır (Saussure, 1974); göstergenin iki bileşeni vardır, gösterilen (düşünce ya da zihindeki imge) ve gösteren (bir ses ya da görsel bir imge; söz gelimi konuşmaya ya da yazıya dökülen kelime ya da ifade). Gösterilen ile gösteren arasındaki bağlantı hiçbir zaman sabit değildir; diğer bir ifadeyle, gösterge her zaman, belli ölçüde keyfîdir. Gösterilen ile gösteren arasındaki bağlantının açıklığı dilin her zaman düzanlamsaldan (fizikî bir varlığa parmakla işaret etmek ve "kedi” demekte olduğu halinden) daha fazla bir içeriğe sahip olmasını beraberinde getirir. Bunun sonucunda "anlam" hiçbir zaman tamamen göndergesel değildir ve her zaman tartışmaya açılabilir. İşaretleme sürecinde oldukça önemli bir role sahip olan dilsel araçların farkına vardığımızda bu açıklık özellikle görünür hale gelir. Örneğin, sosyal bilimler, metaforik doğası farkedilemeyecek kadar yaygın olan, "toplum”u bir bedenmiş̧̧esine düşündüğümüz ve teorileştirdiğimiz organik metaforda olduğu gibi metaforlarla doludur. Teknik söylemler, belirgin kurallar vasıtasıyla göstergeyle anlam arasındaki bağlantıyı sabitleyerek, genelde bu tür bir açıklığı sınırlandırmaya çalışırlar. Bilimsel söylemlerin gelişim süreçleri içinde, Kuhn'un tanımladığı şekilde, az ya da çok keskin bir paradigma kayması sergilemelerinin nedeni budur. $\mathrm{Bu}$ paradigma kaymaları esnasında belirli kavramlar terkedilir ve yeni kavramlar kabul edilir; normal konuşmadaki değişim ise, aynı göstergenin kullanımındaki gözlemlenmesi neredeyse imkânsız kaymalar içerisinden ve daha tedrici bir şekilde gerçekleşir. 
Söylem, düşünce, iletişim ve eylem için bir araç sunar; bir söylemin kendine ait bir iç düzeni vardır; ama sadece uzmanlaşmış ve teknik söylemler içinde güçlü bir tutarlılık arz eder. Bir söylem, diğer söylemlerle arasındaki sınırları değişen ölçülerde açık olan bir sistem ya da yapıdır. Bu tanıma göre, söylemler söylenenlerin bir kısmını desteklerken diğerlerine ket vurarak, söylemsel olasılıkları "kontrol etmek”ten ziyade "iletirler". "Söylemsel oluşum” kavramının birbirine rakip versiyonları olmakla birlikte (bu yazıda Foucault'nun kullanımını göz önüne alacağız) bir ölçüde güvenilir toplu söylemler açısından bu tür bir kavramın gerekli olduğunu ileri sürüyoruz. Örneğin sosyoloji, toplumsala dair birbirine rakip söylemler sistemi olarak resmedilebilir; bu söylemler tanımlanabilen ancak değişen prosedürel kurallarla işlerler. Öte yandan, toplumsala dair popüler söylemler de vardır. Bu popüler söylemlerde, toplumsal bölünmeler, cinsellik, toplumsal değerler vb. farklı şekillerde resmedilirler. Popüler söylemler üzerine yapılan en zengin incelemelerden birinde, Pierre Bourdieu, Fransız toplumunda bulunan, ahlâki değerlerden sofra adabına, siyasal bağlantılardan spora kadar uzanan bir yelpazede yer alan söylemlerin karşıt sınıfsal boyutlarını açığa çıkarır (Bourdieu, 1984).

Söylemlerin yeteri kadar ilgi görmeyen bir yönü söylemlerin üretimiyle kullanım biçimleri arasındaki ilişsidir. Örneğin Foucault, profesyonel söylemlerin üretimini herkesten daha fazla vurgulamıştır. İncelemediği konulardan biri ise "popüler söylemler"dir. Dolayısıyla, Foucault'nun ana ilgi konusunu oluşturan cinsellikle ilgili söylemler söz konusu olduğunda, profesyonel söylemler arasındaki güç dengelerinin değişiminden derinden etkilendikleri halde profesyonel söylemlere indirgenmesi mümkün olmayan, birbirine rakip popüler söylemleri belirlemenin faydalı olduğunu ileri sürüyoruz. Böyle bir iştigal, ideoloji teorisinin, değişken söylemsel yayılımların haritasını çıkarmanın ötesine geçerek hep olan ve genelde görünmeyen söylemsel mücadelelerin ideolojik etkilerini irdelemek için değissen güçler dengesinin nedensel bir açıklamasına doğru yol almasını sağlayan önemli bir açılım sağlar.

Söylem teorisiyle boğuşan birçok teorisyeni uğraştıran, birbiriyle ilişkili iki soru var: Söylem kuramı, bütün iletişimsel pratikleri söylemsel kılacak ölçüde geniş mi? Bu sorunun alternatif versiyonu ise şu şekilde kurulur: Söylemin dışında kalan herhangi bir şey var mı? Derrida'nın hiç tereddüt etmeden "metnin dişında kalan hiçbir şey yoktur" dediğini biliyoruz (Derrida, 1974: 158). Öte yandan, söylem teorisini destekleyenlerin çoğunluğu, hiçbir şeyin söylemin dışında olamayacağı görüşünü benimsemeyi reddederler. $\mathrm{Bu}$, Marksizm ile söylem teorisinin karşılaşmasını İngilizce'de başlatan Hindess ve Hirst için geçerlidir. Hindess ve Hirst radikal bir kesinlikle ideolojinin yerine söylemi geçirirken söylemin dışında herhangi bir 
şey olmadığı görüşüne açık bir şekilde direnmişlerdir (Hindess ve Hirst, 1977). Buna çok benzer bir şekilde Foucault, söylemsel olan ve söylemsel olmayan alanlar arasındaki ayrımı korumak gerektiğinin altını çizer (Foucault, 1972). Öte yandan, aşağıda da göreceğimiz gibi Laclau ve Mouffe, söylemsel olanla söylemsel olmayan arasındaki ayrıma karşı çıkarlar (Laclay ve Mouffe, 1985: 105-114).

$\mathrm{Bu}$ oldukça soyut—ama her halükârda önemli-meselede bir çözüme varmak niyetinde değiliz. Daha ziyade, bu soruların sorulmasına yol açan koşullara dair argümanlarımızı ileri sürmenin uygun olduğunu düşünüyoruz-bunu yapmak soru(n)lar ortadan kaldırmıyor; ama neden bu kadar önemli bir konuma geldiklerini göstermemize yardımcı oluyor. "Toplumsal”a özgün bir giriş yapmaya yönelik bütün çabalar-ister söylemden ister ideolojiden doğru olsun- “toplumsal”'1 birleştirici bir kavramsallaştırma içinde toparlama girişimine bağlı olarak aşırı yayılma ("söylem dışında kalan hiçbir şey yoktur", “iktidar her yerdedir”, vb.) riskiyle yüzleşmek durumunda kalırlar. Aslında, her şeyi içerimlemeye yönelik bütünleştirici eğilim mantığını harekete geçirerek, yeğlenen özgünlük kavramsallaştırmasının aleyhine işleyen tam da bu, "toplumsal"ın sınırsız olma özelliğinin genel kabul görmesidir. Daha sağduyulu bir stratejinin hem bütünleştici hem de külliyen reddedici stratejiye karşı çıkmak olduğunu ileri sürüyoruz. Buna göre, söylemi teorileştirmeye yönelik farklı girişimlerin her bir versiyonunun önerdiği ya da karşı çıktı̆̆ı sınırların sonuçlarına dikkat etmeliyiz. Bu uyarı Foucault'nun söylem teorisini nasıl kurduğunu soruştururken kendi yaklaşımımızı geliştirmemizi sağlayacaktır.

\section{Michel Foucault: Söylem Karşısında İdeoloji}

Foucault ile Marksizm arasındaki ilişkilenmenin izini süremk kolay değildir. Foucault, yeri geldiğinde farklı biçimlerde Marx'a selam verirken oldukça genel terimlerle vulgarize bir Marksizm'den bahseder. 1960'lar ve 1970’ler boyunca Fransız Marksizmi’ni etkilemiş olan yüksek teori patlaması içerisinde yer alan eğilimlere ilgi göstermemiş olması dikkat çekicidir.

Burada sunduğumuz okuma Marksizm ile Foucault arasındaki mesafeyi azaltmayı amaçlıyor. Söylemi ideolojiye karşıt bir şekilde konumlandıran okumalar içerisinde önemli bir hat, Althusser ile Foucault'nun karşı karşıya getirilmesine dayanır. Oysa Foucault şu konuda 1srarlıdır: "İlk olarak son yirmi yıl süresince yaptığım çalışmalarla neyi amaçladığımı söylemek isterim. Bu, iktidar olgusunu incelemek değildi. (...) Daha ziyade, kültürümüzdeki, insanların farklı tarzlarda özne kılınmalarının bir tarihini yaratmayı hedefledim" (Foucault, 1982: 208). 
Ama Althusser ile Foucault arasinda esasa dair bir fark var: Althusser'in tasavvuru tahakkümün yeniden üretimi sorunsalı içerisine sağlam bir şekilde oturmuştu. Foucault için ise daimi bir tereddütten bahsedebiliriz. Bir yandan, tahakkümü açığa çıkarmaya kararlı olduğu açıktır; ama öte yandan, tahakkümü herhangi bir şekilde homojenleştirmekten kaçınmaya çalışır. Foucault, söylem ile ideolojiyi kesin bir şekilde ayırmakta 1srar ederek bu sorunlardan kaçınmaya çalışırken Althusser, adı konmamış bir “söylem teorisi”ni ideoloji teorisinin bir parçası haline getirir. ${ }^{4}$

Foucault ne öğrencisi olduğu Althusser'le ne de iktidar sorununa merkezî önem atfeden Poulantzas'la açıkça ilişkilenir. Foucault'nun Marksizm'le ilişkilenirken başvurduğu strateji, bizatihi genel teori tasarısından kaçınarak, Marksizm'in mıntıkasından uzak durmaktır. Batı Marksizmi klasik Marksizm'in açmazlarıyla iştigal olarak tanımlanabilirse Foucault'nun eserlerinin Batı Marksizmi’nin karşılaştığı sorunlara karşı bir yanıt olarak okunması mümkündür.

Foucault'nun Batı Marksizmi’yle karşılaşmasının bizi ilgilendiren özgün alanı sadece ideoloji kavramından değil, aynı zamanda bu kavramın geçerli olduğu alandan da bilinçli bir şekilde imtina etme çabasıdır. Foucault'ya göre modern disipline edici toplumun ortaya çıkışı "ideolojiden hem çok daha fazlasını hem de çok daha azını içerir. Bu, bilginin oluşumu ve birikimi için etkili araçların üretimidir-gözlem yöntemleri, kayıt teknikleri, sorgulama ve araştırma prosedürleri, denetim aygıtları” (Foucault, 1980: 102). Bu süreçlerin göz ard1 edilemeyecek derecede "maddi" olduklarını, diğer bir ifadeyle, fikirler ya da bilinç sorunsalına kilitlenmiş ideoloji kavramıyla karşılanamayacaklarını düşünür. İdeoloji, "hakikat olduğu zannedilen bir şeyin her zaman karşısındadır” (Foucault, 1980: 118) Ona göre, “[M]esele insanların bilincini (...) değil (...) hakikat üretiminin siyasal, ekonomik ve kurumsal rejimini değiştirmektir (...) Özetle, siyasal sorun yanılgı, yanılsama, yabancılaşmış bilinç ya da ideoloji değil, hakikatin kendisidir” (Foucault, 1980: 133).

Söylemler, az çok saptırılmış gerçekliğin temsilleri değildirler; daha ziyade, (bizzat ilettikleri kendilerine içkin teknoloji, taktikler, iktidarın etkileri) "ekonomiler" olarak anlaşılmalıdırlar. Diğer bir ifadeyle, iktidar söylemlerin içine kazınmıştır; dışında yer almaz. Yanı sıra Foucault, ideolojinin Özne’ye dair teorik bir hümanizmanın içine hapsolduğunu düşünür.

Marksizm söz konusu olduğunda, ideoloji düzeyinde iktidarın etkilerini ortaya çıkarmaya çalışanlardan değilim. Aslında, ideoloji sorununu gündeme getirmeden önce beden sorununu ve iktidarın beden üzerindeki etkilerini çalışmanın daha materyalist olup olmayacağını merak ediyorum. Zira bu analizlerde beni rahatsız eden şey, istisnasız olarak, klasik felsefenin sunduğu 
model üzerinden kurulan ve iktidarın sonradan ele geçirdiği düşünülen bilinçle

donatılmış bir insan öznenin baştan kabul edilmesidir (Foucault, 1980: 58).

Dolayısıyla, söylem gizleyen olarak tanımlayıp geçebileceğimiz bir şey değildir. Aksine, "uğruna mücadele edilen ve mücadeleye aracı olan şeydir; söylem ele geçirilecek iktidardır" (Foucault, 1981: 52-53).

Foucault, söylemi ideolojiye karşıt bir konuma oturtur. Ancak, eleştirel ve sosyolojik ideoloji anlayışları arasında yaptığımız ayrıştırmayı yeniden gündeme alacak olursak bu ilişkilenme o kadar da basit değildir. Foucault'nun teorik hümanizmayı ve hakikat/sahtelik ikiliğini reddi herhangi bir eleştirel ideoloji nosyonu karşısında hiç de muğlâk olmayan bir konum almasını sağlar. Öte yandan, söylemin mücadelenin aracısı olduğuna dair görüşü, Marx'ın ideolojiyi insanların söz konusu çatışmanın bilincine vardıkları ve bu çatışmayı çözmek için kavga verdikleri alan olarak kavramsallaştırmasındaki merkezî fikri yansıtır. Foucault'nun söylem anlayışı bu açıdan, Batı Marksizmi'nde ideolojinin ele alınış biçiminde ana ekseni oluşturan "sosyolojik" ideoloji versiyonuna çok benzer.

Öyleyse, Foucault'nun söylem ve ideoloji arasında kurduğu ayrıma rağmen iki kavram arasındaki boşluk, onun ileri sürdüğü kadar geniş değildir. Birçok açıdan Batı Marksizmi’ndeki ideoloji anlatısının Foucault'nun söylemi ele alış biçimine yeğlenebileceğini düşünüyoruz. Foucault'nun söylem anlatısı gözle görülür şekilde yapısalcı olmaya devam etti. Söylemler, kurumsallaşmış üretim alanlarından çıkarak yayılırlar ve tipik olarak “profesyonel"dirler. Dolayısıyla, söylemler "dayatılırlar", diğer bir ifadeyle insanların söylemden doğru "içerisine sokuldukları" özne konumlarını üretirler. Buradaki çelişkili sonuç, Foucault'nun en önde gelen temalarından biri, iktidarın olduğu yerde direnişin de olduğu teziyken, bu direnişin doğasının bizatihi alternatif söylemlerin üretimi olarak görülmesidir.

Foucault'nun yapısalcı söylem okumasının diğer bir özelliği, bu okumanın oldukça düz ve bütünleştirici tarih anlatılarına kapı açmasıdır. Bu tarih anlatılarında egemen söylemler kendi rasyonalitelerini muhataplarının söylemsel imkânlarına dayatırlar. Burada, direniş söylemlerine hammadde sağlayan söylemlerin içindeki çelişkiler bir yana gerilimlerin bile hiç hesaba katılmaması dikkat çekicidir. Foucault'nun eserlerinin bu yazıdaki amacımızla en fazla ilişkili özelliği söylem ile toplumsal kurumlar arasındaki ilişkiyi anlama çabasıdır. Her bir toplumsal pratik kümesi Foucault'nun ifadesiyle "söylemsel oluşum” olarak adlandırdığ şeyin içinde yerleşiktir ve bu oluşum tarafından yapılandırılır. Foucault'nun yaklaşımının orijinal yanı, söylemlerin nispeten istikrarlı bir alanda toplanmasından ibaret değildir. Foucault, söylemsel oluşum kavramının kullanılmasında iki açıdan ilerleme kaydetmiştir. İlk 
olarak, bir formasyon oluşturan söylemsel bildirimler sisteminin salt bir birlik olmadığı, aynı zamanda "dağılma"yı yücelttiğinde 1srar eder (Foucault, 1972: 38). İkincisi, "söylemsel oluşum” kavramı dikkati kendi varoluş koşullarına yönlendirir. Basitçe söylemek gerekirse, Foucault dikakti söz konusu formasyonu mümkün k1lan koşullara yönlendirir. Dikkati, göstergeler, gösterenler, gösterilenleri oluşturan öğelerin iç dinamiklerinden uzaklaştırır. Söylemsel oluşum tanımı, söylemlerin oluşturulduğu ve dönüştürüldüğü dış ya da toplumsal koşullara odaklanmak amacıyla yapısalcı dilbilimin kendi içindeki uğraşlarından ayrılır. Foucault'nun söylem teorisinin dilbilimsel olmayan bir teori olduğunu vurgulamak onun benimsediği konumlara gereğinden fazla değer yüklendiği anlamına gelmez. Aslında bir açıdan Foucault, söylemsel oluşumların keskin bir şekilde toplumsal ya da hattâ materyalist bir incelemesini sunar. Yapmaya çalıştığ 1 şeyin öneminin ve en önemlisi ideoloji teorisiyle uyumlulaştırılabilirliğinin ya da bağdaşabilirliğinin altını çiziyoruz.

Önemli bir açıdan Foucault, ideoloji hakkında titizlikle tasarlanmış ilişsisel bir açıklamanın temellerini atmak için Marx'dan çok daha ileri gitmiş̧ir: İdeolojinin toplumsal ve kurumsal pratikler bileşkesinden doğuşunu anlatma imkânını sunar. Böylelikle, Marksizm'in başını ağrıtan bir gidişattan, "nedenler" ya da "kökenler"e—söz gelimi, kapitalist sınıfın ihtiyaçlarına ya da sermayenin dalaveresine başvurmaya - dayalı teleolojik açıklamalara yenik düşmekten kaçınmamızı sağlar.

Foucault, bazı yeni kurumsal pratiklerin—hapishane, akıl hastanesi vb.—ortaya çıkışını sağlayan koşulları ve şartları somut tarihsel bir perspektiften çalışmak için bir çerçeve sunar. Tam da bu bağlamda, Foucault'nun "her şey söylemden ibarettir" saptamasına işaret eden şifahi savrulmalara rağmen bu konumu devam ettirememesinin ve ayn zamanda görececiliğe kaymaya direnişinin nedenlerini artık görebiliriz. Söylemsel oluşumların, kurumsal ve ilişkisel önkoşullarını belirleyerek, kurumsal pratiklere katkısını açıklama çabası Foucault'nun benimsemeye çok yaklaştığı görececilikle ilişkisini kontrol altında tutar.

Böylece, Foucault'nun söylemsel olan ve söylemsel olmayan pratikler arasında yaptığ ayrımı anlayabiliriz. Bu çerçevede söylemsel olmayan pratikler, "söylemin tamamından ya da, söylemin nesnelerinin tümünden bağımsız olarak var olan, kurumlar, teknikler ve toplumsal formlar arasında tanımlanabilen (...) ilksel ilişkiler” olarak görülür Foucault, 1972: 45). Bu, Foucault'nun, söylemin dlşında bir yerde bir alan olduğunu düşündüğü anlamına gelmez. Zira bütün pratikler ve kurumlar söylem aracillğıyla işler. Daha ziyade, toplumsal pratikler ve kurumlar söylemlere indirgenemez; sadece söylemden kaynaklanmayan, kendilerine ait imkân koşulları vardır. 
Foucault'nun söylem teorisinin, söylemlerin genelde toplumsal pratik, özelde muhalif mücadeleler açısından sonuçları ya da önemini- “ideolojik etki” olarak tanımlamıştıkaçıklamakta neden yetersiz kaldığını artık anlayabilecek durumdayız (Laclau, 1977). Foucault'nun yerelin bilgisine epistemolojik bağlılığı, doğrusal toplumsal "ilerleme"yle ilgili bütün önermeleri dışarıda bırakmaya gösterdiği özen ve büyük teoriye yönelik derin kuşkusu bu kusurun/eksikliğin nedenleridir. Bir tahakküm tarzından diğerine geçişle ilgili açıklamaları, direnişin sadece yeni ve çok daha yayılmacı tahakküm biçimlerine yol açtığı yönünde, oldukça kasvetli bir açıklamaya doğru ilerler. Ancak, nedensel sonuçlar ya da "etkiler"e yönelik açık bir ilginin dışarıda bırakılmasının daha çok koşullara bağlı oduğu ve dolayısıyla çok daha kolay telafi edilebileceğini ileri sürüyoruz. İki farklı, ancak çelişkili olmayan neden arasında belirli bir taviz ilişkisi bulunmaktadır. Foucault dikkatini, özgül tarihsel sonuçların ihtimal dâhilinde olmasını sağlayan koşullara (ya da varoluş koşullarına) vermişti. Akıl hastanesiinin ya da hapishanenin "icadı” na yol açan koşullar nelerdi? Foucault, "sonuç" ya da "etki”yle ilgili sorular sormaya meyletmedi: Ak1l hastaneleri, hapishaneler, vb. ne tür sonuçlar doğurdu? Öte yandan, Foucault'nun söylem analizinde bu tür soruşturmaları engelleyen ya da hem sonuç hem de etkiyle ilgili sorularla ilgili araştırma yapmayı yasaklayan herhangi bir kısıtlamanın olmadığını ileri sürüyoruz.

Foucault'nun söylem teorisini önerdiğimiz şekilde okumanın önemi, kendisi, ideoloji teorisi geleneğinden tamamen kopmayı açıkça amaçlamışken kaydettiği ilerlemelerin bu gelenekle bağdaşabilirliğinden kaynaklanıyor. Aslınd, Foucault'nun, söylem ve kurumsal pratikler arasındaki etkileşim ve bağlantıdan doğru tam anlamıyla sosyolojik bir ideoloji anlatısı ortaya koyarak kayda değer açılımlar sunduğunu ileri sürmekle bir adım ileri gitmiş olduk.

\section{Post-Marksizm ve Söylem}

Bugün post-Marksizm'in ayrıştırıcı özelliklerinden biri söylem kavramının ideoloji kavramını yerinden etmesidir. $\mathrm{Bu}$, ideoloji kavramının ortadan kalktığı ya da terkedildiği anlamına gelmez. Daha ziyade, bu kavramın kullanımının, post-Marksizm'in savunucularının ilişkilerini kesmek istedikleri Marksist öğeleri, özellikle indirgemeciliği ve ekonomizmi çağrıştırmasına işaret eder. Bu ilişik kesme ya da kopuş bir kez işlemeye başladığında ideoloji kavramının savunmaya geçmeden yeniden dolaşıma sokulabileceğini, ideolojinin ne demek olmadığı hakkında gereğinden fazla parantez içi nota gerek kalmadan yeniden kullanılmaya başlayabileceğini ileri süreceğiz. Bu bölümde, post-Marksist söylem teorisinin en gelişmiş açıklamasını sundukları için Laclau ve Mouffe'un çalışmalarına odaklanıyoruz. 
Marksizm'den post-Marksizm'e doğru uzun yürüyüşste Ernesto Laclau'nun sosyolojik ideoloji yaklaşımına kayda değer katkısının olduğunu ve Chantal Mouffe'un Gramsci'nin hegemonya kavramının potansiyelini açımladığını hatırlamak önemli (Mouffe, 1979). Her ikisi de, siyasal öncülerin sinıf mücadelesinde silah olarak ustalıkla kullandıkları, önceden şekillendirilmiş “fikir” sistemleri olarak tanımlanan ideoloji nosyonunda, Gramsci'nin başlattığı kırılmayı daha da ileriye götürmek için birçok şey yaptılar. Laclau, zihinsel öğelerin, kavramların, vb. zorunlu olarak sınıfsal ya da siyasal sonuçları olmadığını (örneğin "milliyetçiliğin” herhangi bir sınıfsal konuma bağlı olmadığını) vurguladı.

“Eklemlenme” kavramı Laclau ve Mouffe'un erken dönem çalışmalarıyla bugünkü konumları arasındaki temel bağıntıyı kurar. Bu kavram, en basit haliyle, söylemlerin ve ideolojilerin, önceden belirlenmiş sınıfsal ya da siyasal öneme sahip olmayan öğeleri birbirlerine yakınlaştırarak ve birleştirerek ortaya çıkışına odaklanır. Her bir söylemi ideolojik açıdan önemli kılan ya da ideolojik etkiye sahip olmasını sağlayan farklı öğelerin birleşme biçimleridir. $^{5}$

Laclau ve Mouffe'un en ilgi çekici teorik katkılarından biri eklemlenme teorisini daha detaylı bir şekilde geliştirmiş oldukları söylem anlatısının içine yerleştirmiş olmalarıdır. Foucault'nun söylemsel olanla söylemsel olmayan arasında yaptığı ayrıştırmayı reddederler; aksine, araştırma ya da bilgi nesnelerini bütünüyle söylemsel olarak görürler. Öte yandan, tüm bilgi nesnelerinin söylemselliğiyle, felsefenin bilinçten bağımsız bir şekilde var olan bir dış gerçeklik olup olmadığı yönündeki kadim sorusu arasında zorunlu bir bağlantı olmadığı konusunda ısrarcıdırlar. Şüphesiz ki, depremler meydana gelir ve meydana gelişleri bilinçten bağımsızdır; ama "tektonik plaka hareketleri" mi, "tanrıların laneti"nin dışavurumu mu olduklarını söylemsel kurulumları belirler. Laclau ve Mouffe'un argümanlarını açımlamak için "her şey söylemseldir" sloganını reddetmemiz gerekiyor; bu slogan bilginin, istisnasız söylem içerisinde yerleşik olduğu yönündeki çok daha ilgi çekici iddiayı kapatıyor.

Söylem toplumsal ilişkiler kurar; diğer bir ifadeyle, her türlü bilginin, konuşmanın, argümanın, tecrübenin muhatapları açısından anlam kazanmasının ötesinde toplumsal ilişkiler içinde paylaşılan ve iletilebilen bir anlam kazanmasını sağlayan bir bağlamda gerçekleşir. Laclau ve Mouffe, Foucault'nun söylem ile söylemsel oluşum arasında yaptığı ayrıma dikkate değer bir şekilde açıklık kazandırırlar. Bir söylemsel oluşum, hiçbir zaman, tamamen "kapalı" değildir; diğer bir ifadeyle, sadece bazı bildirimlere izin veren ve diğerlerini dışarıda bırakan birleşik ya da sınırlandırılmış bir sistem sunmaz. Foucault'nun tıp söylemiyle ilgili olarak belirttiği gibi, "bu söylemi kodlanmış ve normatif bir bildirim sistemi olarak tanımlamaya kalktığımızda, [söylemin kurduğu] tıbbın göründüğü anda parçalarına ayrıldığını kabul 
etmemiz gerekir" (Foucault, 1972: 34). Daha ziyade, her söylemsel oluşum bir ölçüde açıktır ve (bütün disiplinlerin tarihinde çok önemli bir role sahip olan birleştirme projeleri, tutarlılık arayışı göz ardı edilmemek kaydıyla) birlikle değil, dağılmayla, seçimle, bölünmeyle ve muhalefetle nitelenir.

Söylemsel oluşumların birliğinin, genel kanının aksine olacak şekilde bozulması neden önemli? Bu hamle, bilginin sabit temellerini ya da anlamın garantisini aramaya devam etmeyi reddeden epistemolojik bir stratejinin bir parçası olmasının yanı sıra, Dünya Görüşü [Weltanschauung] olarak İdeoloji’yle ilgili bütünselleştirici nosyonlardan geri çekilmenin de bir parçasıdır. Ama bu genel argümanın ötesinde iki sonuç daha var. İlki bizi “eklemlenme”ye geri götürüyor. Bize, söylemin öğelerinin eklemlenmesinin hep geçici olduğunu, diğer bir ifadeyle anlamın hiçbir zaman tam anlamıyla garanti altına alınmadığını? hatırlatıyor. Bunun en doğrudan sonucu, aynı söylemsel oluşum içinde farklı söylemlerin ortaya çıkabilmesidir. $\mathrm{Bu}$ ise bizi, ikinci ve daha siyasal olan argümana-söylemlerin her zaman alternatiflerin ve mücadelenin etkilerine tâbi oldukları yönündeki argümanagötürüyor: "Bütün söylemler söylemsellik alanına egemen olma, farklılığın akışına el koyma, bir merkez inşa etme çabası olarak ortaya çıkar” (Laclau ve Mouffe, 1985: 105-114).

Bu açık ve ihtilaflı söylem kavrayışı Laclau ve Mouffe'un, ekonomizmi Marksizm'in tarihinden nihai olarak çıkartma amaçlarında önemli bir role sahiptir. Laclau ve Mouffe'un toplumsal ilişkilerin söylemsel doğasında ısrar etmeleri, söylemlerin "özneleri” kurduklarına yönelik tezi geliştirme biçimlerinde anlam kazanır. Hiçbir özne konumu, verili herhangi bir farklılıklar kümesine dayanılarak sabitlenemez. Laclau ve Mouffe, kadınların ezilmelerinin arkasında daha önceden belirlenmiş bir mekanizmanın olduğu ya da dişil bir özden bahsedilebileceğini ileri süren özcü feminizme karşı geliştirdikleri eleştirilerinde bu fikri oldukça etkili bir şekilde uygulamaya koyarlar. ${ }^{6}$ Özcü feminizm, dikkatimizin cinsellik/cinsiyet sisteminin tarihsel olarak değişen biçimlerini oluşturan birbirinden farklı pratiklerden kaymasına ya da hattâ bu pratiklere hiç odaklanamamamıza neden olur.

Öte yandan, birbirinden ayrı unsurların özgün söylemsel kurulumlara eklemlenmesine yapılan vurgu özcülükten uzaklaşmak açısından faydalı olsa da, kendi içinde sınırlıdır. Burada şu soruya odaklanacağız: Herhangi bir özgün söylem içerisinde bir araya gelebilecek unsurların birleşmesinin belirli bir sınırı var mıdır? $\mathrm{Bu}$ soruyu yanıtlamak için Foucault'nun söylemsel oluşumlarla ilgili argümanlarına dönmemiz gerekiyor. Foucault, her bir söylemsel oluşumun varlık koşullarını belirleyen “oluşum kuralları"nı tariflemeyi vaat eder. Buna bağlı olarak hiçbir zaman tam anlamıyla geliştirmediği bir dizi kavram önerir; "belirme yüzeyleri”, “sınır tayin eden otoriteler" ve "belirleme ölçütleri”ne işaret eder 
(Foucault, 1972: 41-42). Burada söz konusu olan, bir söylemin içerisine doğduğu—kurumsal çerçeve gibi-söylemsel olmayan unsurların söylemin gelişimini nasıl sınırlandırdığını saptama çabasıdır. Laclau ve Mouffe ise, Althusser'in “üst-belirlenim” kavramını yeniden gündeme getirirler. Cinsel farklılıkların nasıl teorik çerçeve içerisinden okunması gerektiği sorusuyla ilgili olarak "çeşitli cinsel farklılıklar arasındaki üst-belirlenim sistematik olarak cinsel bölünme sonucuna yol açar” iddiasında bulunurlar (Laclau ve Mouffe, 1985: 117). Ama "üst-belirlenim"in bu bağlamda, aralarındaki eklemlenmenin özgün bir söylemi tanımladığı birbirinden ayrı öğelerin olası bileşimlerini sınırlandıran koşulların olup olmadığı yönündeki gerçekten zor soruya yanıt bulmak için hiçbir şey yapmadan "eklemlenme"ye bir alternatif olarak işlediği söylenebilir.

Laclau ve Mouffe'un ortaya attıkları, ancak tatmin edici bir çözüme ulaştırmadıkları sorun "eklemlenme" ve "üst-belirlenim"in tanımlanması sorununun ötesine geçmenin bir yolunu bulmaktır. Söylemsel oluşumların ortaya çıkışını etkileyen kısıtların tanımlanabilmesini sağlayacak uygun terimler bulmak gerekmektedir. Bu meseleyi ele almak için, buraya kadar attığımız adımların yeniden izini sürmek ve Gramsci’nin bu konuda bir çözümün geniş bir çerçevesini hâlihazırda çizmiş olup olmadığını hesaba katmak gerekiyor. Bunun yanıtı ise, Laclau ve Mouffe'un bu çözümü arama yollarının aksine, Gramsci’ninhegemonya kavrayışını değil—ortak kanı kavrayışını yeniden kurmakta bulunabilir.

\section{Gramsci ve Hall: Ortak Kanı Üzerine}

Gramsci'nin “ortak kanı” ve kültür üzerine anlatısında hegemonik bir projenin inşasında dilin stratejik rolü görünürlük kazanır.

[F]elsefe bir dünya görüşüdür ve (...) felsefî etkinlik sistematik olarak tutarlı kavramların "bireysel" açıdan irdelenmesinin ötesinde ve her şeyden önce popüler "zihniyet"i dönüştürmek ve felsefî yenilikleri somut bir şekilde-diğer bir ifadeyle, tarihsel ve toplumsal olarak-evrensel olarak sergilenecek biçimde yaymak için verilen kültürel bir savaştır. Bütün bunlar göz önüne alındığında genelde dil, teknik anlamda diller meselesi incelememizde ön planda yer almalıdır (Gramsci, 1971: 348).

Buradaki örneğe gereğinden fazla anlam yüklememeye dikkat etmek gerekiyor. Dil, Gramsci'nin analizlerinde odak noktasında yer almaz. Öte yandan, Gramsci'nin, dil, ideoloji ve hegemonya arasındaki bağlantıya hiçbir zaman tam anlamıyla odaklanmasa da, dilin taşıdığı önemin oldukça farkında olduğu söylenebilir. Gramsci’nin bu bağlantıya yeterli teorik ilgiyi göstermemesi, kısmen, bu kavramlar arasındaki kavramsal örtüşmeden kaynaklanıyor olabilir. Stuart Hall'un belirttiği gibi 
Gramsci "ideoloji” terimini (...) bugün klasik addedilebilecek bir şekilde, fikirler sistemi olarak (...) ama geniş bir bağlamda (...) kullanır: [bu kullanım] "kelimenin en üst anlamıyla, sanatta, hukukta, ekonomik faaliyette ve bireysel ve kolektif yaşamın tüm tezahürlerinde saklı olan dünya görüşü olarak kullanılması şartı"na [bağlıdır]. Gramsci ideolojiyi aynı zamanda tarihsel işlevlere bağlı olarak da ele alır: "[b]ir toplumsal bloğun tümünün ideolojik bütünlüğünü muhafaza etmek"teki rolü; bireylere ve gruplara, eylemlerini etkileyen ve değiştiren [kendilerine özgü] farkl1 "dünya görüşleri" sunması ve her şeyden önce, "insan kitlelerini örgütleyen ve erkeklerin ${ }^{7}$ hareket ettikleri, konumları hakkında bilinçlendikleri, mücadele ettikleri" bir alan olması itibariyle [değerlendirir] (Hall, 1988: 55).

$\mathrm{Bu}$ formülasyonlar iki şekilde okunabilir. İlk olarak, geniş bir okuma yapılabilir ve Lovejoy’un bilinç dışı zihinsel alışkanlıklar olarak adlandırdığ ş̧eyin kurulmasında söylemin rolüne odaklanılabilir (Lovejoy, 1936: 7). İnançlar, tutumlar ve önvarsayımlar formel bir argüman içerisinden geliştirilmezler; daha ziyade dilsel bir pratiğin içerisinden örtük olarak baştan kabul edilirler. Dolayısıyla söylem, her ne kadar Gramsci'nin kullandığı bir kavram olmasa da, incelenmelerini gereksiz kılacak derecede doğal görünen düşünme tarzlarını beraberinde getirir. Öte yandan ikinci okumaya göre - ki bu okuma Gramsci'nin yaklaşımının orijinal yanını oluşturur - daha somut ya da yapılandırılmış bir söylem nosyonu ortaya çıkar. $\mathrm{Bu}$, Gramsci'nin ortak kanı tanımının ve dolayısıyla "söylem" kavramının Anthony Giddens'ın, “toplumsal sistemlerin yeniden üretimine tekrar tekrar karışan kurallar ve kaynaklar olarak" tanımladığı "yapı" kavramsallaştırmasına ne kadar yakın olduğunu fark ettiğimizde açıklık kazanır. "Yapı sadece, insan bilebilirliğinin organik temeli olan bellek kalıntıları ve eylem içinde anlık bir oluş halinde var olur” (Giddens, 1984: 16). Ortak kanı (ya da popüler söylem) hem toplumsal eylemin aracısıdır hem de toplumsal eylemin yeniden ürettiği toplumsal ilişkileri kurar.

Ortak kanının bu, neredeyse yapısal özellikleri bir yana, Gramsci, "sağduyu"yla kurduğu olumlu bağlantıda örneklendiği gibi aktif bir “ortak kanı” tanımını kuşatmayı başarır-Gramsci bu yolla ortak kanının her zaman için reaksiyoner ya da geleneksel olmadığında ısrar eder. Tam da bu noktada, Foucault'nun iktidarın direnişi tetiklediği yönündeki hükmü vasıtasıyla başa çıkmaya çalıştığı sorunla karşılaşıyoruz. Foucault bu açıdan, disipline edici toplumun gittikçe daha fazla hissedilen pençeleri göz önüne alındığında direnişin nasıl mümkün olabileceği konusunda tam anlamıyla ikna edici bir argüman hiçbir zaman geliştirememiştir. Buradaki sorunu şöyle ifade edebiliriz: Ortak kanıyı yaşanmış tecrübenin sorgusuz kabul edilen aracısı olarak görürsek herhangi bir alternatif mümkün olabilir mi? Egemen söylemlerin bizi böylesine kurdukları ve dolayısıyla direnişin imkânsız 
kılındığı kasvetli bir senaryodan nasıl kaçabiliriz? Direniş, "sağduyu” ya da muhalefet nereden gelir? Gramsci’nin yanıtı eksiktir; zira en doğrudan yanıtında alternatif bir failin“modern Prens"in, ezilenlerle arasındaki organik bağlantı vasıtasıyla direnişi keşfedebilen, ifadelendirebilen ve öncülügünü yapabilen devrimci partinin-hâlihazırda mevcut olduğu varsayılır. Stratejik siyasal müdahale ihtimaline bağlılı̆̆ımızı devam ettirmeyi arzuluyorken, devrimci eylemlilik fikrine Gramsci’ye kıyasla daha fazla kuşkuyla yaklaşıyoruz. Buna rağmen, direnişin mümkün olduğu ve direnişe en az meyilli olan koşullardan çıktığı saptaması doğruluğunu koruyor.

Gramsci’nin, dönüştürücü “ortak kanı”yı siyasal pratik içerisinden üretmenin öneminde ısrar etmesi Stuart Hall'un çalışmalarının merkezî temalarından birini oluşturur. Dönüştürücü kapasite, artık, söz gelimi Leninizm'de olduğu gibi, daha yüksek ya da yükseltilmiş bir bilinç düzeyinin edinilmesi olarak anlaşılmıyor. İngiltere'de Thatcherizm'in yükselişi de düşüşü de Hall'un son on yıl içindeki çalışmalarının başat vesileleri olarak işlev gördü. Hall'un ele aldığı soru, hem emeğin hem de yeni toplumsal hareketlerin çıkarlarının böylesine karşısında duran amaçlar güden bir rejimin nasıl olup da siyasal hâkimiyetini inşa edebildiği ve sürdürebildiği ve akabinde bu hâkimiyeti hızla kaybettiğidir. Bu soruya yanıt ararken, Gramsci ve söylem teorisindeki son dönem gelişmelere dayanan Hall, söylem ve ideoloji arasındaki ilişki üzerine en kışkırtıcı argümanların bir kısmını ileri sürmüştür.

Ancak, Hall'un çalışmaları ideolojiyle söylem arasında Gramsci'dekine benzer bir örtüşmeye doğru ilerler. Bizi ideoloji ile söylem arasındaki bağlantıyla ilgilenmeye iten de bu örtüşmedir. Örneğin Hall ideolojiyi şöyle tanımlar: "Farklı sınıfların ve toplumsal grupların toplumun işleyiş biçimini anlamlandırmak, tanımlamak, çözmek ve anlaşılır kılmak için etkin bir şekilde kullandıkları zihinsel çerçeveler — diller, kavramlar, kategoriler, düşünce imgelemi ve temsil sistemleri” (Hall, 1983: 59).

Başka bir yerde, “Thatcherizm söylemi, bütünüyle, ideolojik öğeleri söylemsel bir zincirde birleştirir. Bunu söylemin mantığının ya da birliğinin birtakım özgül özne konumları olduğu varsayımından hareketle hitap edilen özneye dayanmasına neden olacak şekilde yapar” (Hall, 1988: 49). Bu, söylemlerin, tarihsel bir bloğun egemenliğini güvenceye almak için birbirinden ayrık toplumsal öğeleri nasıl birleştirdiğini teorik açıdan okumaya yönelik paha biçilmez bir adımdır. Öte yandan Hall'un formülasyonu, söylemsel öğelerin birleştirilme sürecinin neden göz ardı edilemez bir biçimde ideolojik bir sonuca yol açtı̆̆ını açıklamakta yetersiz kalır.

Hall, Althusser'in, toplumsal öznelerin çağırılma süreci boyunca kurulumları hakkındaki düşünceleri üzerine geliştirdiği kısmî eleştiride de, benzer şekilde, şu argümanları 
ileri sürer: “Ídeolojinin üretimi ve mekanizmalarıyla ilgilenen herkes öznelerin üretimine ve belirli özne biçimlerinin ortaya çıkmasını sağlayan bilinç dışı kategorilere bakmalıdır. Yeni Sağ'ın söylemlerinin, söz konusu yeni özne konumlarının üretimiyle ve öznelliklerin dönüşümüyle uğraştıkları açıktır” (Hall, 1988: 46; vurgu bize ait). Burada Hall, hem ideolojinin üretiminden hem de mekanizmalarından bahseder. Ancak ardından, söz konusu mekanizmanın söylem olduğuna işaret ettiği söylenebilir. Hall'un iki terim arasında bir ayrıma gitmekle yaşadığı sorun ikili bir ideoloji görüşünden-hem süreç hem de sonuç olarak ideoloji nosyonunu benimsemesinden-kaynaklanıyor gibidir. Kendi argümanımızı takip ettiğimizde ise, süreç olarak söylem ile sonuç olarak ideoloji üzerinden geliştirilen bir formülün daha cazip olduğunu düşünüyoruz.

\section{İdeolojiyi Geri Kazanmak}

İdeoloji ile söylem arasındaki karşılaşmaların belli başlı evreleri üzerine yukarıda yaptığımız inceleme, ideoloji teorisinin yapıcı rolünün canlandırılmasına olanak sağlar. Söylem teorisine karşı1 duracak ya da söylem teorisinden doğru karşı çıkılacak bir ideoloji teorisi önermiyoruz. Önerdiğimiz ideoloji teorisi, daha ziyade, söylem teorisini tamamlıyor. $\mathrm{Bu}$, ideoloji teorisinin, Marx’ın miras bıraktığından birçok açıdan farklı bir versiyonu. $\mathrm{Bu}$ teori kapsamında fikirler/varlık ayrımının ve bu ayrımın belli başlı epistemolojik sonuçlarının yanı sıra bilinç sorunsalında görünür olan, hümanist öznenin merkezsizleştirilmesini yerinden ediyoruz ve doğru ve yanlış bilinç arasındaki karşıtlığı dışarıda bırakıyoruz. Öte yandan, Marx'ın yaklaşımındaki oldukça önemli bir boyutun temel bir özelliğini koruyoruz ve bu özelliği merkeze oturtuyoruz. Bu özelliği ideoloji teorisinin yön belirleme kapasitesi olarak tanımlamıştık-diğer bir ifadeyle, özne konumlarının egemen toplumsal ilişkileri güçlendirmek ve yeniden üretmek için sistematik bir şekilde işleyişinin odağa yerleştirilmesi. Söz konusu yön belirleme kapasitesinin, söylemsel pratiklerin sonuçlarına bakarken ideolojik analizleri kullanarak yakalandığını ileri sürüyoruz. Nitekim bu argümanımızdan hareketle “ideolojinin etkileri”ne odaklanıyoruz.

“Söylem” ve "söylemsel oluşum” kavramlarını Foucault'dan çıkarsadığımız şekilde birbirinden ayırıyoruz. Bu kavramlar her zaman göstergesel olan, diğer bir ifadeyle, anlam ve hakikat iddialarının üretimiyle ilişkili olan süreçleri tanımlıyor. Ancak bu süreçler, sadece göstergesel olmakla kalmazlar; üretilen anlamların ve öznelliklerin varoluş koşulu olarak, toplumsal pratikleri içeriden işaretlerler. Bu oldukça soyut açıklamanın ne anlama geldiği yukarıda verdiğimiz (s. 17), sıradan, ama tartışmaya açık bir pratikte-erkeklerin kadınlara rutin bir şekilde kapı açmaları-örneklenir. Söylem ile dil arasında kolaya kaçılarak kurulan özdeşlikten kaçınmak için, kapı açmanın göstergebilimsel açıklamasının dile getirilen sözlere 
dayanmadığını belirtmek gerekiyor; bu açıklama, daha ziyade, kapı açılırken, kenara çekilinirken ve eşlik edilirken gözlemlenen abartıdan çıkar; bu toplumsal pratikler kap1 açmanın söylemini oluştururlar. Bu davranış ancak bir grup ayrıştırılmış toplumsal cinsiyet rollerinden ve bu rollerle bağlantılı söylemlerden oluşan bir söylemsel oluşumun parçası olduğu takdirde toplumsal bir anlam kazanır. Öte yandan, söz konusu söylemsel oluşum ideolojik etkisini, ancak patriarkal toplumsal ilişkileri niteleyen sistematik tabiiyet ilişkilerinin ironik bir şekilde tersine çevrilmesi sayesinde tam anlamıyla tesis eder. $\mathrm{Bu}$ etki, tahakküm/tabiiyet ilişkilerine uygun olduğu, bu ilişkilerin yeniden üretimini kolaylaştırdığı ve son olarak, ideolojinin eleştirel ve sosyolojik boyutlarını kadınların bariz bir şekilde farklı muameleye tâbi olmalarının bu tür pratiklerin altında yatan ve bu pratiklerin arka plan koşullarını oluşturan yapısal eşitsizlikleri kapatmasını sağlayan mistifikasyon vasıtasıyla yeniden birleştirdiği için “ideolojik”tir. Dolayısıyla, bazı söylemleri ideolojik yapan, tahakküm sistemleriyle olan ilişkileridir. İdeolojik söylemler yaşanmış tecrübelere katılan gösterge biçimlerini içerirler. Buradaki temel mekanizma kısmî ya da özgül çıkarların evrensel çıkarlar olarak sunulmasıdır.

Söylem ile ideoloji arasında yaptığımız ayrımın söylemsel alanların ve bu alanların potansiyel-ama zorunlu olmayan-ideolojik etkilerinin analizi için genel bir çerçeve çizdiğini düşünüyoruz. Sonuç olarak, söylem ile ideoloji arasında önemli bir ayrım vardır; ancak, bu iki kavram kaçınılmaz bir şekilde karşıt konumlarda yer almazlar; daha ziyade aralarında tamamlama ve yayılma üzerinden işleyen bir bağlantı vardır.

\section{Kaynakça}

Althusser, L. (1971). Ideology and Ideological State Apparatuses. Lenin and Philosophy and Other Essays içinde. Londra: New Left Books.

Bernstein, R. (1983). Beyond Objectivism and Relativism: Science, Hermeneutics and Praxis. Oxford: Basil Blackwell.

Williams, R. (1980). Problems in Materialism and Culture. Londra: Verso.

Williams, R. (1977). Marxism and Literature. Oxford: Oxford University Press.

Bourdieu, P. (1984). Distinction. Londra: Routledge.

de Saussure, F. (1974). Course in General Linguistics. Londra: Fontana.

Derrida, J. (1974). Of Grammatology. Baltimore: John Hopkins University Press.

Gramsci, A. (1985). Quaderni del carcere. Cilt 2 Gerratana, V. (der.) Turin: Eunaidi.

Gramsci, A. (1971). Selections from the Prison Notebooks. Hoare, Q. ve Smith, G. N. (çev. ve der.). Londra: Lawrence \& Wishart. 
Giddens, A. (1984). The Constitution of Society. Berkeley: University of California Press.

Hall, S. (1988). The Toad in the Garden: Thatcher Among the Theorists. Nelson, C. ve Grossberg, L. (der.) içinde. Marxism and the Interpretation of Culture. Urbana: University of Illinois Press.

Hall, S. (1983). The Problem of ldeology. Matthews, B. (der.) içinde. Marx 100 Years On. Londra: Lawrence \& Wishart.

Hall, S. (1977). Culture, the Media and the "Ideological Effect". Curran, J vd. (der) içinde. Mass Communications and Society. Londra: Edward Arnold.

Hindess, B. ve Hirst, P. (1977). Mode of Production and Social Formation. Londra: Macmillan.

Foucault, M. (1982). The Subject and Power. Dreyfus, H. L. ve Rabinow, P. (der.) içinde. Michel Foucault. Chicago: University of Chicago Press.

Foucault, M. (1981). The Order of Discourse. Young, R.J. (der.) içinde. Untying the Text. Londra: Routledge.

Foucault, M. (1980). Power/Knowledge. Brighton: Harvester Press.

Foucault, M. (1972). The Archaeology of Knowledge. New York: Pantheon Books.

Laclau, E. ve Mouffe, C. (1985). Hegemony and Socialist Strategy. Londra: Verso.

Laclau, E. (1977). Politics and Ideology in Marxist Theory. Londra: Verso.

Larrain, J. (1983). Marxism and Ideology. Londra: Macmillan.

Lovejoy, A. (1936). The Great Chain of Being. Cambridge, Mass.: Harvard University Press.

Marx, K. ve Engels, F. (1976). The German Ideology. Karl Marx-Frederick Engels Collected Works Cilt 5 içinde. New York: International Publishers.

Mouffe, C. (1979). Hegemony and Ideology in Gramsci. Mouffe, C. (ed). Gramsci and Marxist Theory içinde. Londra: Routledge.

\footnotetext{
${ }^{1}$ Burada, fikirler sistemi olarak tanımlanan büyük harfli İdeoloji’yi tamamen dışarıda bıraktığımızı belirtmemiz gerekiyor.

${ }^{2}$ Purvis ve Hunt burada, İngilizce'deki eril yapılanmaya eleştirel bir vurgu yapıyor. İngilizce'de "erkekler" teriminin aynı zamanda "insan"1 işaretlemek için kullanılmasının örneklediği cinsiyetçiliği vurgulamak için "sic" (metinde olduğu haliyle) ibaresini kullanıyorlar (ç.n.)

3 "Yaşanmış tecrübe"ye verilen önem Althusser'in güvenceye aldığı önemli bir gelişmeydi. Öte yandan Althusser, idoloji alanını "gerçek ilişkiler" alanında ayrıştırmak için "imgelem" terimini kullanmakla bu çizgiden sapmıştır (Althusser, 1971).

${ }^{4}$ 1970’lerin ortasında, Péecheux ideolojiyle söylem arasındaki bu bağlantıyı açığa çıkarıyordu (Pécheux, 1982).

${ }^{5}$ Gramsci bu yeniden eklemlenme sürecini şu şekilde açıklar: "Eleştiri vasıtasıyla farklılaşma ve değişim süreci eski ideolojilerin bir zamanlar sahip oldukları itibarları oranında mümkündür. Önceden ikincil ve tabi, ya da hattâ arızi olan artık birincil konumuna getirilir - yeni bir ideolojik ve teorik bütünün çekirdeği haline gelir” (Gramsci, 1975: 1058).

${ }^{6}$ Burada, Laclau ve Mouffe'un argümanlarını somutlamak için, diğer herhangi bir ideolojik-teorik çizgiyi değil de, feminizm içerisindeki özcü çizgiyi masaya yatırmaları, bir yandan feminist eksende bir halleşmenin örneği olarak okunabilecekken, diğer yandan feminist perspektiften post-Marksizm içerisindeki eril damarla ilişkili olarak okunabilir. Purvis ve Hunt'ın Laclau ve Mouffe'un evrenselci-özcü bilme biçimlerine muhalif mühaleleri arasından biricik örnek olarak özcü feminizme getirdikleri eleştiriyi biricik örnek olarak sunmaları da benzer bir şekilde değerlendirilebilir. (ç.n.)

${ }^{7}$ Burada yine, 2. sonnotta belirttiğim, İngilizce'deki eril yapılanmanın Hall'dan yapılan alıntıya sızmasına dikkat çekmek için, orijinal metinde "insanlar”a tekabül edecek şekilde kullanılmış olan men terimini “erkekler” olarak çeviriyorum.
} 